\title{
Discretionary Accounting Choice and Management Opportunistic Behavior to Manage Income
}

\author{
Theresia Trisanti \\ Accounting Department, Sekolah Tinggi Ilmu Ekonomi YKPN Yogyakarta \\ Jl. Seturan Raya, Kledokan, Caturtunggal, Depok, Sleman, Yogyakarta 55281, Indonesia \\ E-mail: theresiatrisanti@gmail.com
}

\begin{abstract}
Income smoothing (IS) practice is "the smoothing of fluctuations company income levels that are considered normal for company". IS manipulation has a clear goal, which is to generate income flows that continue increase stably. There are several ways that companies can use to do IS practice for example: changes in accounting methods. In this research, income smoothing practices of Indonesian listed manufacturing firms were detected through empirical tests using changes in discretionary accounting (DAC). Samples of listed manufacturing companies classified as smoothing and non-smoothing using Moses smoothing behavior index. The results show that the possible motivation of DAC transactions is income smoothing. Two independent variables such as institutional ownership and external audit quality have a significant positive effect on IS practice but the company size has no influence on IS practice.
\end{abstract}

Keywords: Discretionary accounting changes; income smoothing practices; institutional ownership; external audit quality; type of industry.

\section{INTRODUCTION}

As suggested by the Financial Accounting Standard Board, Statement of Financial Accounting Concepts No.1, the main objective of financial statements is to provide information that is useful to present for potential investors and others in making rational investment, credit and similar decisions. The usefulness of financial and other statements is affected by the quality of reporting. The quality financial reports are should be relevant (timely) and reliable (verifiable and unbiased) its means financial statements free of material misstatements due to errors and fraud [37]. The result of this high quality information is that it is useful in analyzing the past and predicting the future. For capital markets to function efficiently and effectively, participants (including investors and creditors) must have confidence in the financial reporting process. Financial statement fraud, as we've all seen recently, is a serious threat to this confidence. Manager as a preparer of financial reports, should be able to communicate the information and safeguard its relevance and reliability. When manager incentives are based on their companies' financial performance, it may be in their self-interest to give the appearance of better performance through income smoothing practices. In many companies, managers are compensated both directly (in terms of salary and bonus) and indirectly (in terms of prestige, future promotions, and job security) depending on a firm's income performance relative to some pre-established benchmark. This combination of management's discretion over reported income and the effect these income have on their compensation leads to a potential agency problem [9,18,28].

Beyond the management compensation problem, income smoothing practices may impact investors by giving them false information. Capital markets use financial information to set security prices. Investors use financial information to decide whether to buy, sell, or hold securities. Market efficiency is based upon the information flow to capital markets. When the information is incorrect, it may not be possible for the markets to value securities correctly. To the extent that income smoothing practices obscures real performance and lessens the ability of shareholders to make informed decisions, we can view income smoothing practices as an agency cost. As a result, financial reporting quality has been the subject of serious criticism in recent years $[13,18,50]$.

The IS practices will not only result non real company financial reports but in the long term it could also lead to an extreme and complex manipulations to meet the increasing internal sales target and external stakeholders' expectation. Although it is highly risky, existing literature has documented evidences that company managers actively engage 
in IS practices [4]. Furthermore, in comparison to their developed-country counterparts, IS practices in developing and emerging economies are higher. The multiple incentives of income smoothing practices might also have motivated Indonesian firms to manipulate their financial statements to have smoother income figures [7,17,42]. Since Indonesia developing countries and has an emerging capital market (i.e. highly-concentrated ownership, developing legal infrastructure), therefore it is important to examine the relationship between DAC and IS practices and also to identify factors affect the IS practice in Indonesian public listed company.

According to [21] agency theory is the relationship or contract between principal and agent. The agency theory has the assumption that each individual is solely motivated by his or her own interests, causing a conflict of interest between principal and agent. Agency Theory shows that firms can be seen as a loosely defined relationship between resource holders. An agency relationship arises when one or more individuals, called principals, employ one or more other individuals, called agents, to perform certain services and then delegate decision-making authority to agents. Agency Theory formally originated in the early 1970s, but the concept behind it has a long and varied history. Among these are the influence of property-rights theory, organizational economics, contract law, and political philosophy. The main agency relationships in the business are those between shareholders and managers, between debtholders and shareholders. This relationship is not always harmonious, indeed, agency theory relates to agency conflict, or conflicts of interest between agents and perpetrators. This has implications for corporate governance and business ethics. When agencies occur they tend to incur agency costs, for an example: costs incurred in order to maintain effective agency relationships (e.g, offering performance management bonuses to encourage managers to act in the interest of shareholders) [22,31,43].

Agency Theory poses a fundamental problem in the organization of "self-serving behavior". Company manager may have personal goals that compete with the goal of maximizing shareholder wealth. Because shareholder managers have the right to manage corporate assets, a potential conflict of interest arises between the two groups. Agency Theory could be used to understand the practice of IS that it is a result of conflicting interests between the principal and agents especially on how agents response to the contract of their compensation structure. Some researchers have speculated that managers (agents) benefit from smoothing income due to the structure of compensation incentives $[12,35]$.
IS practices defined as "the intentional dampening of fluctuations about some level of income that is currently considered to be normal for a firm", some researchers defines income smoothing as "a means used by management to diminish the variability of a stream of reported income numbers relative to some perceived target stream by the manipulation of artificial (accounting) or real (transactional). According to [36] "income smoothing is the process of manipulating the time profile of income or income reports to make the reported income stream less variable, while not increasing reported income over the long run". Therefore, income smoothing manipulation has a clear objective, which is to produce a steadily growing stream of profits [11,24,36].

Furthermore, research in income smoothing practices has shown that there are plenty of tools available for income smoothing practices, especially when managers' interests are threatened. For example, for the purpose of manipulating share prices, managers of buyout firms have an incentive to 'understate' income through controlling the changes in revenues and depreciable capital, while managers of firms about to make an initial public offering have an incentive to 'overstate' income by exercising discretion in depreciation policies and bad debt allowances [23]. Indeed, firms are known to change accounting estimates and accounting methods when they are close to debt covenant violation. Even firms that have violated debt covenants implement income-increasing accounting changes to improve their bargaining power for future renegotiation. In addition to these incentives for managers to engage in income smoothing practices, academic research finds that there are motivations for managers to circumvent regulatory requirements. For instance, banks are likely to overstate loan loss provisions and understate loan write-offs when they are close to the minimum capital requirement threshold. Having an incentive to obtain more benefits from import relief, firms may understate income during import relief investigation [3,47].

Moreover, accounting income had two major components: cash flows from operations and accounting adjustments called accruals. The generally accepted accounting principles (GAAP) allows certain discretion to report accounting accruals, there is a possibility that accruals contain management expectations about future cash flows or management's intention to manipulate information. Since the determination of signs and sizes of accruals needs a practitioner's judgment and estimation, accruals are vulnerable to manipulation at the discretion of opportunistic managers. But not all the accruals are the result of income manipula- 
tion. Some accrual adjustments are necessary and appropriate and need to be applied on a regular basis. Some researchers attempted to decompose total accruals into discretionary and non-discretionary components, according to them income smoothing practices was believed to be related to the discretionary accruals element $[16,33,46]$.

\section{Hypothesis Development}

As explain in the review literature section, for this study the discretionary accounting change was selected as a smoothing device for several reasons. First, accounting policy changes can have a material impact on reported income and consequently are unlikely to be adopted without management consideration of the effects. Second, no assumption needs to be made concerning the magnitude of the discretionary component of an accounting change $[6,45]$. In addition, findings in smoothing practices can be sensitive to the way the discretionary component is isolated. Accounting changes, however, provide a measure that is purely discretionary. Accordingly the hypothesis for this study is stated as follows:

H1: There is a significant relationship between the discretionary accounting changes and the level of income smoothing practices by Indonesian listed firms

\section{Insitutional Ownership}

[8] find that institutional investors are effective in deterring managers' opportunistic behavior. Thus, greater ownership of stock by outside investors may result in lower agency conflict between managers (agent) and shareholders (principal) as suggested by Agency Theory. The theory asserts that both principal and agent are assumed to be motivated solely by self-interest, that is, to maximize their subjective utility. The agent is striving to maximize the contractual fee he receives subject to the necessary effort level. The principal is striving to maximize the returns from the use of his resources subject to the fee payable to the agent. Institutional investor provides strong incentives for institutions to actively monitor and influence management actions and its various policy decisions and institutional investor are also generally expected to be able to use current information to predict future earnings better than non-institutional investors $[14,15,20]$.

Research on institutional monitoring and opportunistic earnings management finds evidence that the presence of large institutional shareholdings inhibit managers from managing accruals to achieve desired level of income. Results show that when managers have incentives to increase or decrease reported income as revealed from the cash-flow performance for current versus future periods, they accomplish the objective by using income-increasing or income-decreasing discretionary accruals to maintain a desired earnings stream. [29] and [26] suggest that with the increase in shareholdings in a particular firm, institutional investors have strong incentives to monitor management to increase firm value by focusing more on long-term profitability instead of managing income on a year-by-year basis.

Another research by [34] concludes that market reaction arising from the behavior of sophisticated investors (institutional investors) occurs earlier than that of non-sophisticated investors. They argue that sophisticated investors have access to more information from other sources, more timely information, and are also more capable of decomposing earnings into discretionary and non-discretionary components. While in the Indonesian context, [44] find evidence that high institutional ownership constrains earnings management in those firms. Accordingly, for the purpose of this study, the hypothesis is stated as follows:

H2: There is a significant relationship between the IS practices and the institutional ownership in the company.

\section{External Auditor Quality}

As Agency Theory assumes that the managers may act in their own best self-interest, which may, at times, conflict with the owner's best interest, it concerns with the various monitoring mechanisms to minimize this conflict. The external auditor could then be consider as monitoring mechanisms to minimize this conflict and, at the same time is intended to enhance the credibility of the financial statements of a firm. External auditors are supposed to verify and certify the quality of financial statements and give the assurance about the financial report quality issued by the management. Several studies examine the association between external auditor quality and earnings management. Research evidence suggests that the large audit firms are perceived to perform a higher audit quality than smaller audit firms [27,41].

The type of auditors is selected as an explanatory variable in this study to determine whether the magnitude of IS practices is a function of the type of auditors. The types of external auditors are categorized into groups; before 1998 the "Big six" firms (Arthur Andersen, Deloitte and Touche, Peat Marwick Mitchell, Ernst and Young, Cooper and Lybrand, and Price Waterhouse) or after 1998 the "Big four" firms (Deloitte Touché Tohmatsu, KPMG, Ernst \& Young, and Price Waterhouse Cooper) and "non- Big-six" firms (other than the big 
six or big four firm). The "Big six or four", which operate throughout the world with high reputation, are expected to be unlikely involved in and associated with income smoothing practices. On the other hand, the "non-Big-six-or-four" firms are hypothesized to be as less reputable and lower prestige is expected to have more tolerance with their clients [10,27,41]. External auditors' size is used to measure external audit quality, where one for firms audited by Big 6 or 4 auditors (high audit quality) and zero for firms audited by non-Big 6 or 4 auditors (low audit quality). Accordingly, the hypothesis is as follows:

H3: There is a significant relationship between the IS practices and the quality of external audit firms.

\section{Company Size}

In many studies, company size is hypothesized as one of the variables affecting income smoothing behavior. Firm size is often used as a proxy for information availability in the market. Information for large firms should be more available in the market than for small firms. Previous studies found that company size had an effect on income smoothing behavior. For example, research by $[25,38]$ stated that large firms are subject to more public scrutiny than smaller firms, and large upward and downward fluctuations of the earnings of larger firms will attract more attention of regulators and financial analysts. Some researcher have an opposite view and argue that more information is available about larger firms which are closely scrutinized by analysts and investors. Smoothed income signals from larger firms add little value. Therefore, they have less incentive to smooth income. Meanwhile smaller companies are likely to be subject to less public scrutiny than larger companies. Consequently, small companies are expected to smooth income significantly more than large companies [30,49]. Accordingly, the relevant hypothesis is as follows:

H4: There is a significant relationship between the IS practices and the company size.

\section{RESEARCH METHOD}

The research methodology of this study is based on the study of [32] and [40] because it is the most applicable method for the data provided by Indonesia listed companies and there is no need to make estimations about the discretionary and nondiscretionary parts of smoothing instruments. [32] accepts discretionary accounting changes (DACs) as income-smoothing instruments and thinks that firms try to smooth their income figures by using DACs. A discretionary accounting change can have a big impact on the reported income and cannot be done without management's discretion. It is impossible to know real intents of managers; therefore, [32] assumes income smoothing to be one of the possible motivations of DACs rather than assuming the purpose of DACs is always income smoothing.

According to [32] smoothing was measured as the degree to which an accounting change shifts income toward expected income (EE). For each sample firm the income number that would have been reported had the firm not adopted the accounting change was determined and termed pre-change income (PE). A measure of smoothing behavior (SB) was calculated by comparing the deviations of pre change and reported income (RE) from expectations. Therefore PE, RE, and EE are all un-deflated measures and consequently dependent on firm sales was used here as a deflator [32]. Based on this model income smoothing is measured as the degree to which an accounting change shifts income toward expected income (EE). The calculation of pre-change income (PE) is the income number that would have been reported had the firm not adopted the accounting policy change.

$\mathrm{SB}=\frac{|\mathrm{PE}-\mathrm{EE}|-\mathrm{RE}-\mathrm{EE} \mid}{\mathrm{SALES}}$

Where:

$\mathrm{SB}=$ the smoothing behavior,

$\mathrm{PE}=$ the pre-change earnings,

$\mathrm{EE}=$ the expected earnings,

$\mathrm{RE}=$ the reported earnings.

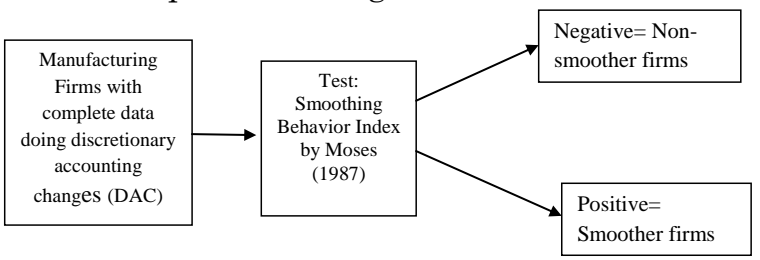

Figure 1. The Sample Selection

A measure of smoothing behavior is calculated by comparing the deviations of pre-change and reported income from expectations. Since PE, $\mathrm{RE}$, and $\mathrm{EE}$ are all un-deflated measures and consequently dependent on sales are used here as a deflator. A simple random walk model (SRWM), predicting income in any year as equal to reported income in the previous year, is used for the tests in this study. It is because the expected income depend solely on the most currently observed income [1]. In this model, it is assumed that the management making discretionary accounting changes to keep the current year's income level at least equal to the last year [6]. Smoother and nonsmoother firms are distinguished by the sign of the amount that is generated by the application of the 
above formula. Positive values of SB mean the analyzed firm is an income smoother [32]. Figure 1 shows the diagram of the sample selection.

\section{Analysis to Determine the Direct Smoothing Instrument}

The smoothing instruments are the variables used by managers in attempting to smooth particular accounting figures. According to [6] and [39] an accounting practice or measurement rule must possess certain properties before it may be used as a manipulative smoothing instrument. Therefore for this research the observations on the notes of financial statements refer to the changes in accounting policies.

\section{Changes in Accounting Policies}

Accounting policy changes have been suspect used to manipulate accounting data. The discretionary accounting changes was selected as smoothing instruments because they can give a material impact on reported income and are unlikely to be adopted without management consideration of the effects [5].

The Indonesian Financial Accounting Standards (PSAK 25, paragraph 6), accounting policies are the specific principles, bases, conventions, rules and practices adopted by an enterprise in preparing and presenting financial statements. Users need to be able to compare the financial statements or enterprise over a period of time to identify trends in its financial positions, performance and cash flows. Therefore, the same accounting policies are normally adopted in each period. A change in accounting policy should be made only if required by the company's statute, or by an accounting standard setting body or if change will result in a more appropriate presentation of events or transactions in the financial statements of the enterprise. Table 1 list the type of DAC.

Table 1 Discretionary Accounting Policies Changes

\begin{tabular}{ll}
\hline No & Description \\
\hline 1 & $\begin{array}{l}\text { Change in estimates life of property, plant assets } \\
\text { and equipment }\end{array}$ \\
2 & Change in depreciation or amortization method \\
3 & Change in capitalizing or expensing policies \\
4 & Change in inventory valuation method \\
5 & Change in deferred taxation method \\
6 & Change in income recognition method \\
7 & Others \\
\hline Sources: Adapted and revised from: $[6][19]$
\end{tabular}

Sources: Adapted and revised from: [6] [19]

\section{Source of Data, Sample Selection and Statis- tical Method}

The population of interest selected for this study comprised manufacturing firms listed on the
Indonesia Stock Exchange and the DataStream database were used for the period of 2013 up to 2017. The term smoothing implies adjustments to income smoothing in two or more consecutive periods and it required analysis of data for at least four periods. The results of some studies suggest that an increase in the time period tends to reduce errors of misclassification of firms as smoothers and non-smoothers, therefore this study has employed a five year time series data collections.

The method of data analysis used in this research is quantitative method, the sampling method is purposive sampling and the independent t-test was use to analyze the data. Each sample should have a complete financial annual report for each period observed. Then, the occurrence of discretionary accounting changes were scrutinized from the notes of financial reports and audit reports. These companies were then tested using the smoothing behavior model. After the test of the smoothing behavior model the researcher expected to get the result of the smoothers and non-smoothers for each year. T-Test was applied in order to find out whether significant differences between smoother and non-smoother firms exist according to each of the explanatory variables. Because the classification of smoother and non-smoother firms changed according to the model used to estimate expected earnings, $t$-test were applied for each smoothers and non-smoothers pair. Like [6], 90 percent confidence level has been selected, predicted the direction of association between the variables and smoothing behavior, so researcher used one-tailed significance results to make evaluations. However, hypotheses of this study do not indicate the expected direction of the association and therefore two-tailed significance results were used.

\section{RESULT AND DISCUSSION}

The observation on the notes of the financial reports and auditor reports of the firms were made to find out the consistency of the selection of accounting methods. These observations were made on financial reports to determine the tendency of using DAC. After going through the annual audit reports, the nature of the DAC was subsequently classified into five major categories according to their types as shown in Table 2.

As seen in Table 2, managers mostly preferred to change their capitalization and/or expense policies, and then to change depreciation/amortization methods. The third most prevalent DAC type is change in inventory valuation methods. From the sample of firms doing DAC selected in this stage, the researcher calculated an "expected" income number that the firms would use to smooth 
their income. Expected income are used as a reference point from which measures of the deviation of actual income can be developed [2]. Positive values of smoothing behavior (SB) mean that the analyzed firm is an income smoother. By using a smoothing behavior index, firms were categorized as smoothers and non-smoothers. Table 3 shows the number of smoother and non-smoother firms that were determined according to simple random walk model (SRWM) model.

Table 2. Firms Doing Discretionary Accounting (DAC) Changes by Year

\begin{tabular}{|c|c|c|c|c|c|c|}
\hline No & Description & 2013 & 2014 & 2015 & 52016 & 2017 \\
\hline 1 & $\begin{array}{l}\text { Change in estimates life } \\
\text { of property, plant assets } \\
\text { and equipment }\end{array}$ & 7 & 6 & 5 & 6 & 5 \\
\hline 2 & $\begin{array}{l}\text { Change in depreciation } \\
\text { or amortization method }\end{array}$ & 4 & 6 & 7 & 8 & 8 \\
\hline 3 & $\begin{array}{l}\text { Change in capitalizing } \\
\text { or expensing policies }\end{array}$ & 10 & 5 & 5 & 8 & 7 \\
\hline 4 & $\begin{array}{l}\text { Change in inventory } \\
\text { valuation method }\end{array}$ & 8 & 7 & 6 & 5 & 3 \\
\hline 5 & $\begin{array}{l}\text { Change in revenue } \\
\text { recognition }\end{array}$ & 6 & 5 & 4 & 7 & 6 \\
\hline 6 & Others & 5 & 4 & 4 & 3 & 6 \\
\hline \multicolumn{2}{|c|}{ Total firms doing DAC } & 40 & 33 & 31 & 37 & 35 \\
\hline
\end{tabular}

Table 3. Smoother and Non-smoother Firms According to SRWM Model

\begin{tabular}{cccccc}
\hline & Total firms & & \multicolumn{3}{c}{ Non- } \\
Year & doing DAC & Smoother & $\%$ & Smoother & $\%$ \\
\hline 2013 & 40 & 32 & 80 & 8 & 20 \\
2014 & 33 & 26 & 78 & 7 & 22 \\
2015 & 31 & 27 & 87 & 4 & 13 \\
2016 & 37 & 30 & 81 & 7 & 19 \\
2017 & 35 & 30 & 85 & 5 & 15 \\
\hline
\end{tabular}

In the first year (2013) there were $8(80 \%)$ of the sample firms had positive SB values and therefore were classified as income smoothers. In the second year (2014) there are 26 firms (78\%) of the sample firms had positive values of SB and they were classified as smoothers from the total of 33 firms. In the last years, on the last year in 2017 there were 30 firms (85\%) out of 35 firms had positive SB values. This findings concluded that the highest percentage of using DAC $(87 \%)$ in 2015, and the lowest of DAC (78\%) in 2014 and also assert that Indonesian listed firms tend to use DAC as income smoothing instrument to smooth their income figure.

In order to find out whether significant differences between smoother and non-smoother firms exist according to each of the explanatory variables, independent Sample $t$-test were applied [6] [48]. Because the classification of smoother and non-smoother firms changed according to the each of the explanatory variables, $t$-test was applied for each smoothers and non-smoothers for 5 years, 95 percent confidence level has been selected.

For independent sample $t$-test, if the variances are equal in both groups, then the p-value ("Sig.") will be greater than 0.05 . However, if the pvalue is less than 0.05 , then the variances are unequal. In this case, all the results have p-value greater than 0.05 for Levene's test, so researcher can conclude that the results are equal variances and researcher looks at the Equal variances assumed column result. Looking down this column from the result we can see that the group means are significantly different as the value in the "Sig. (2-tailed)".

As seen in table 4 for $\mathrm{H}_{2}$ this study hypothesized that there is a significant relationship between Institutional ownership and the level of income smoothing practices by Indonesian listed firms. There is a significant relationship between the IS practices and the institutional ownership in the company. Currently the role of institutional investors has been increasingly important in financial markets. Institutional investors hold a significant fraction of the shares of public firms and some of them actively monitor the firms in their investment portfolios. Some researchers suggests that institutional investors can act as external governance devices, their research evidence shows that institutional ownership can act as good for governance for company,

This study hypothesized that there is a significant relationship between the IS practices and the external auditor quality $\left(\mathrm{H}_{3}\right)$. Auditors working in Big Four public accountant firms are deemed to have the ability and more expertise in auditing than non-big four, so the resulting information is more qualified. The big four auditor has experience and high reputation in limiting the amount of earnings management among the people. If the auditor can't keep his reputation, then it will raises public doubts about the auditor's ability. Auditor considered failed to perform its role as an auditor.

Table 4 shows that in all the five periods the type of company size has no significant relationship with the behavior of IS practices. These negative significant results allow the present researcher to confirm the null hypothesis and this leads the researcher to discard the industry type factor as an explanatory variable. This evidence therefore is not consistent with PAT arguments. The explanation is that for Indonesian listed firm, the IS practices do not depend to the company size but do on firm's performance and income smoothing practices are more likely to be present when a firm's performance is usually bad or in loss condition. 
Table 4. Independent Sample t-Test for period 2013-2016

\begin{tabular}{|c|c|c|c|c|c|c|c|c|c|c|}
\hline \multirow{2}{*}{$\begin{array}{c}\text { Levene's Test } \\
\text { for Equality of } \\
\text { Variance }\end{array}$} & \multicolumn{2}{|c|}{2013} & \multicolumn{2}{|c|}{2014} & \multicolumn{2}{|c|}{2015} & \multicolumn{2}{|c|}{2016} & \multicolumn{2}{|c|}{2017} \\
\hline & $\mathrm{F}$ & $\begin{array}{c}\text { Sign. } \\
\text { (2tailed) }\end{array}$ & $\mathrm{F}$ & $\begin{array}{c}\text { Sign. } \\
\text { (2tailed) }\end{array}$ & $\mathrm{F}$ & $\begin{array}{c}\text { Sign. } \\
\text { (2tailed) }\end{array}$ & $\mathrm{F}$ & $\begin{array}{c}\text { Sign. } \\
\text { (2tailed) }\end{array}$ & $\mathrm{F}$ & $\begin{array}{c}\text { Sign. } \\
\text { (2tailed) }\end{array}$ \\
\hline $\begin{array}{l}\text { Institutional } \\
\text { ownership }\left(\mathrm{H}_{2}\right)\end{array}$ & 4.0323 & $0.032 * *$ & 3.3781 & $0.039^{* *}$ & 0.7024 & $0.051^{*}$ & 1.58704 & $0.019^{* * *}$ & 1.58704 & $0.041^{* * *}$ \\
\hline $\begin{array}{l}\text { External } \\
\text { Auditor Quality } \\
\left(\mathrm{H}_{3}\right)\end{array}$ & 6.0812 & $0.047^{* * *}$ & 4.0988 & $0.027^{* *}$ & 2.4307 & $0.039^{* *}$ & 5.7340 & $0.047^{* *}$ & 5.7340 & $0.050^{* * *}$ \\
\hline $\begin{array}{l}\text { Company Size } \\
\left(\mathrm{H}_{4}\right)\end{array}$ & 3.0207 & 0.083 & 2.9234 & 0.063 & 2.6020 & 0.2840 & 2.9051 & 0.4301 & 2.9051 & 0.1954 \\
\hline
\end{tabular}

\section{CONCLUSION}

The research objective is to investigate the use of discretionary accounting changes (DAC) as smoothing instrument for smoothing company income. The findings show that the highest percentage of using DAC (87\%) in 2015, and the lowest of DAC (78\%) in 2014. These findings also assert that Indonesian listed firms tend to use DAC as income smoothing instrument to smooth their income. The two independent variables such as profitability and debt financing have positive significant influence to IS practices.

The limitation this study that only focused on publicly manufacturing listed companies in Indonesia, as an emerging capital market. Therefore, the findings reported in this study might not be generalizable to other firms in other countries with different economic and business settings. The suggestions for future research that future research can develop and combine a better IS practice model. It can develop a particular model for each industry, maybe with different industry characteristics, such as the influence of some other IS instruments to company income that might produce different and new IS models.

\section{REFERENCES}

[1] Abdullah, S. N., Ismail, K. N. I. K. and Lode, N. A. (2002). Disclosure of Extraordinary Items and Income Smoothing Behaviour in Malaysia. Jurnal Pengurusan, 21, 57-75.

[2] Acharya, V. V. and Lambrecht, B. M. 2015. A theory of income smoothing when insiders know more than outsiders. The Review of Financial Studies, 28, 9. doi: http://doi.org/ $10.1093 / r f s / h h v 026$

[3] Aljifri, K. (2007). Measurement and Motivations of Earnings Management: A Critical Perspective. Journal of Accounting, Business and Management, 14.

[4] Allayannis, G. and Simko, P. J. 2009. Earnings smoothing, analyst following, and firm value. Analyst Following, and Firm Value (August 25, 2009).

[5] Athanasakou, V. E., Strong, N. C. and Walker, M. (2007). Classificatory income smoothing: The impact of a change in regime of reporting financial performance. Journal of Accounting and Public policy, 26(4), 387-435. doi: http://doi.org/10.1016/j.jaccpubpol.2007.05.002

[6] Atik, A. 2009. Detecting income-smoothing behaviors of Turkish listed companies through empirical tests using discretionary accounting changes. Critical Perspectives on Accounting, 20, 5. doi: http://doi.org/10. 1016/j.cpa.2008.01.003

[7] Berloffa, G. and Modena, F. (2013). Income shocks, coping strategies, and consumption smoothing: An application to Indonesian data. Journal of Asian Economics, 24, 158-171. doi: http://doi.org/10.1016/j.asieco.2012.11.004

[8] Chung, K. H. and Zhang, H. (2011). Corporate governance and institutional ownership. Journal of financial and quantitative analysis, 46(1), 247-273. doi: http://doi.org/10.1017/ s002 2109010000682

[9] Copeland, R. M. and Licastro, R. D. 1968. A note on income smoothing. The Accounting Review, 43, 3.

[10] Dao, M. and Pham, T. (2014). Audit tenure, auditor specialization and audit report lag. Managerial Auditing Journal, 29(6), 490-512. doi: http://doi.org/10.1108/MAJ-07-2013-0906

[11] Elgers, P. T., Pfeiffer Jr, R. J. and Porter, S. L. (2003). Anticipatory income smoothing: a reexamination. Journal of Accounting and Economics, 35(3), 405-422. doi: http://doi.org/10. 1016/S0165-4101(03)00039-9

[12] Fama, E. (2012). Agency problems and the theory of the firm. In The Economic Nature of the Firm: A Reader. Third Edition. doi: http://doi.org/10.1017/CBO9780511817410.022

[13] Gaa, J., and Dunmore, P. September, 2007. The ethics of earnings management. Chartered Accountants Journal of New Zealand, 86, 60-62. http://search.proquest.com/docview/ 
209683743? accountid=14549\%5Cnhttp://hl5y y6xn2p.search.serialssolutions.com/?genre=ar ticle\&sid=ProQ:\&atitle=The+ethics + of + earni ngs + management\&title $=$ Chartered + Accounta nts+Journal+of+New+Zealand\&issn=117299 29\&date $=2007-09-0$

[14] Gaganis, C., Hasan, I. and Pasiouras, F. (2016). Regulations, institutions and income smoothing by managing technical reserves: International evidence from the insurance industry. Omega, 59, 113-129. doi: http://doi. org/10.1016/j.omega.2015.05.010

[15] Gill-de-Albornoz, B., and Markarian, G. 2010. Income Smoothing and Idiosyncratic Volatility. Working Paper, 1-51. http://www.fef.es/ new/images/IEAF/FEF/los-premios-deinvestigacion/premios 2012/INCOME.pdf

[16] Graham, J. R., Harvey, C. R. and Rajgopal, S. (2005). The economic implications of corporate financial reporting. Journal of Accounting and Economics, 40(1-3), 3-73. doi: http://doi. org/10.1016/j.jacceco.2005.01.002

[17] Habib, A. 2005. Firm-specific determinants of income smoothing in Bangladesh: An empirical evaluation. Advances in International Accounting, 18. doi: http://doi.org/10.1016/ S0897-3660(05)18003-9

[18] Heflin, F., Kwon, S. S. and Wild, J. J. (2002). Accounting choices: variation in managerial opportunism. Journal of Business Finance and Accounting, 29(7-8), 1047-1078. doi: http://doi.org/10.1111/1468-5957.00461

[19] Herrmann, D. and Inoue, T. (1996). Income smoothing and incentives by operating condition: an empirical test using depreciation changes in Japan. Journal of International Accounting, Auditing and Taxation, 5(2), 161177.

[20] Iatridis, G. 2010. International Financial Reporting Standards and the quality of financial statement information. International review of financial analysis, 19, 3. doi: http://doi.org/ 10.1016/j.irfa.2010.02.004

[21] Jensen, M. C. and Meckling, W. H. (1976). Theory of the firm: Managerial behavior, agency costs and ownership structure. Journal of Financial Economics, 3(4), 305-360. doi: http://doi.org/10.1016/0304-405X(76)90026-X

[22] Jensen, M., and Meckling, W. (2012). Theory of the firm: Managerial behavior, agency costs, and ownership structure. In The Economic Nature of the Firm: A Reader, Third Edition. http://doi.org/10.1017/CBO9780 511817410.023

[23] Karmon, D. J. and Lubwama, C. W. (1997). An events-study approach to detecting income-smoothing activities: Some evidence from multinational corporations. Journal of International Accounting, Auditing and Taxation, 6(1), 75-95. doi: http://doi.org/10.1016/ S1061-9518(97)90013-6

[24] Koch, B. S. (2010). Smoothing: Experiment, 56(3), 574-586.

[25] Kocmanová, A., Hrebicek, J., and Docekalová, M. 2011. Corporate Governance and Sustainability. Econ Manag, 16, 543-549. http://doi. org/10.4324/9780203390122

[26] Koh, P.-S. (2005). Institutional ownership and income smoothing: Australian evidence. Accounting Research Journal, 18(2), 93-110. doi: http://doi.org/10.1108/10309610580000678

[27] Krishnan, G. V. 2003. Does Big 6 Auditor Industry Expertise, (1991), 1-16. http://doi. org/10.2308/acch.2003.17.s-1.1

[28] Low, M., Davey, H. and Hooper, K. 2008. Accounting scandals, ethical dilemmas and educational challenges. Critical Perspectives on Accounting, 19, 2. doi: http://doi.org/10. 1016/j.cpa.2006.05.010

[29] Luqman, R. A., and Shahzad, F. 2012. An Association between Income Smoothing, Income Tax And Profitability Ratios in Karachi Stock Exchange (An Empirical Investigation). Interdiciplinary Journal of Contemporary Research in Business, 3(9), 986-991.

[30] Lusi, D. and Swastika, T. (2013). Corporate governance, firm size, and earning management: Evidence in Indonesia stock exchange. Journal of Business and Management, 10(4), 77-82.

[31] Morck, R. and Yeung, B. 2003. Agency problems in large family business groups. Entrepreneurship theory and practice, 27, 4. doi: http://doi.org/10.1111/1540-8520.t01-100015

[32] Moses, O. D. 1987. Income smoothing and incentives: Empirical tests using accounting changes. Accounting Review. http://web.a. ebscohost.com / ehost/detail/detail? sid=de4bd 403-8819-4167-afea-97cf89709f2d@sessionm gr4003\&crlhashurl=login.aspx\%3Fdirect $\% 3 D$ true\%26scope\%3Dsite\%26db\%3Dbth\%26AN\% 3D4478528\%26msid\%3D-427778771\&hid= 4207\&vid=0\&bdata $=$ Jmxhbmc9cHQtYnImc2 l0ZT1laG9zdC1s

[33] Namazi, M. and Khansalar, E. 2011. An investigation of the income smoothing behavior of growth and value firms (case study: Tehran stock exchange market). International Business Research, 4, 4. doi: http://doi.org/ 10.5539/ibr.v4n4p84

[34] Nelson, M. W. and Tayler, W. B. 2007. Information pursuit in financial statement analysis: Effects of choice, effort, and reconcilia- 
tion. The Accounting Review, 82, 3. doi: http://doi.org/10.2308/accr.2007.82.3.731

[35] Nkundabanyanga, S. K. and Sserwanga, A. (2011). Firm Risk Profile, Agency Incentives and Corporate Performance: Corporate Governance Perspective of Uganda. Journal of Modern Accounting and Auditing, 7(3), 239.

[36] Prencipe, A., Bar-Yosef, S., Mazzola, P. and Pozza, L. 2011. Income smoothing in familycontrolled companies: Evidence from Italy. Corporate Governance: An International Review, 19, 6. doi: http://doi.org/10.1111/j.1467-8683. 2011.00856.x

[37] Rezaee, Z. 2005. Causes, consequences, and deterence of financial statement fraud. Critical Perspectives on Accounting, 16, 3. doi: http://doi.org/10.1016/S1045-2354(03)00072-8

[38] Richardson, G. D. 1989. Discussion of "Timeliness of financial reporting, the firm size effect, and stock price reactions to annual earnings announcements". Contemporary Accounting Research, 5, 2. doi: http://doi.org/10. 1111/j.1911-3846.1989.tb00722.x

[39] Rydqvist, K., Schwartz, S. T. and Spizman, J. D. (2014). The tax benefit of income smoothing. Journal of Banking and Finance, 38, 78-88. doi: http://doi.org/10.1016/j.jbankfin. 2013.09.017

[40] Saudagaran, S. M. and Sepe, J. F. (1996). Replication of moses'income smoothing tests with canadian and uk data: a note. Journal of Business Finance and Accounting, 23(8), 1219-1222. doi: http://doi.org/10.1111/j.14685957.1996.tb01168.x

[41] Schmidt, J. J. and Wilkins, M. S. (2013). Bringing Darkness to Light: The Influence of Auditor Quality and Audit Committee Expertise on the Timeliness of Financial Statement Restatement Disclosures. Auditing: A Journal of Practice and Theory, 32(1). doi: http://doi.org/10.2308/ajpt-50307

[42] Shanikat, M. and Abbadi, S. S. (2011). Assessment of corporate governance in Jordan:
An empirical study. Australasian Accounting, Business and Finance Journal, 5(3), 93-106. http://search.ebscohost.com/login.aspx?direct= true\&profile $=$ ehost\&scope $=$ site\&authtype $=c r$ awler\&jrnl $=18342000 \& A N=65787409 \& h=Q O$ /629os1HhywAKnab77F69RssQNUMkvUfzI uEA09uRc8drLXG/jvcQEoK7OC9XIw9CM9P JB2Vjs8wYJWe33ng==\&crl=c

[43] Srinidhi, B., Ronen, J. and Maindiratta, A. 2001. Market imperfections as the cause of accounting income smoothing - the case of differential capital access. Review of Quantitative Finance and Accounting, 17, 3. http://resolver.scholarsportal.info/resolve/0924 865x/v17i0003/283_miatcoscodca

[44] Trisanti, T. (2013). The Effect of Non-recurring Item Transactions on the Possibility of Firms to Smooth Income: the Case of Indonesian Listed Firms. Indonesian Journal of Accounting and Auditing, 17(2), 123-134.

[45] Tucker, J. W., and Zarowin, P. A. 2006. Earnings Informativeness?, 81(1), 251-270.

[46] Van Tendeloo, B. and Vanstraelen, A. (2005). Earnings management under German GAAP versus IFRS. European Accounting Review, 14(1), 155-180. doi: http://doi.org/10.1080/ 0963818042000338988

[47] Vyas, D. (2011). The timeliness of accounting write-downs by US financial institutions during the financial crisis of 2007-2008. Journal of accounting research, 49(3), 823-860. doi: http://doi.org/10.1111/j.1475-679X.2011.00410.x

[48] White, G. E. (1970). Discretionary accounting decisions and income normalization. Journal of accounting research, 8(2), 260-273.

[49] Zhou, J., and Elder, R. 2001. Audit Firm Size, Industry Specialization and Earnings Management by Initial Public Offering Firms. State University of New York at Binghamton, (315).

[50] Zhou, W. and Kapoor, G. (2011). Detecting evolutionary financial statement fraud. Decision Support Systems, 50(3), 570-575. doi: http://doi.org/10.1016/j.dss.2010.08.007 